\title{
The Effect of Competence Financial Manager, Internal Control System, and Utilization of Technology Information on the Quality of Financial Report (A Study on Credit Unions In The Kepanjen District)
}

\author{
Angguliyah Rizqi Amaliyah ${ }^{1} \quad$ Gaguk Apriyanto ${ }^{2} \quad$ Sihwahjoeni $^{2}$ \\ 1.Student in Magister Management Program, University of Merdeka Malang, Indonesia \\ 2.Graduate Program, University of Merdeka Malang, Jl. Ters. Raya Dieng, Malang, Indonesia
}

\begin{abstract}
This study aims to examine the effect of competence financial manager, internal control systems, and utilization of technology information on the quality of financial report in credit unions in the Kepanjen District.

The Data used in this study are the data of primary and secondary data. Primary Data is Obtained directly from respondents who provide answers through questionnaires. Secondary Data is Obtained from the data reports that come from Cooperatives through interviews. Using a sample of 45 people in the financial manager section at 11 credit union in Kepanjen District. The results of the study with multiple linear regression analysis indicate that competence financial manager, internal control systems, and utilization of information technology have a positive effect on the quality of financial report. Each variable shows that the competency financial manager does not affect the quality of financial report. The internal control system variables have a positive effect on the quality of financial report.
\end{abstract}

Keywords: Competency, Internal control system, Information technology, Financial report

DOI: $10.7176 / \mathrm{RJFA} / 10-4-12$

\section{Introduction}

Indonesia's economy is structured as a joint venture based on the principle of family in Article 33 paragraph (1) of the Constitution of 1945. The Company stated that the prosperity of the community who preferred not prosperity of a wake-up company and accordingly is the cooperative. Distribution or provision of credit to small and medium enterprises (UKM) is one of the main business and spread almost in the majority of financial institutions, including cooperatives. In cooperative useful quality of financial reporting as a basis for economic decision making for interested parties. Where quality is defined as conformance to the standard, measured based on the levels of nonconformity, and achieved through examination (Mulyana, 2010: 96). It is necessary to implement the existing financial management system.

In a business organization, institution-profit and non-profit system of internal control is absolutely the main thing and very necessary, because the operations and performance requires a special policy that is capable to accommodate and provide limits and special provisions in any implementation out activities, according Tuty (2012: 11). Internal controls are needed to make it easier to find or analyze existing problems or problems that may arise in the process of achieving goals that the achievement of objectives can we know clearly. As well as the use of information technology can contribute to individual communication process effectively, in particular, enables the complete financial report data according to Williams (2003).

Credit Unions as organizations in the economic and social fields is highly vulnerable to the risk of loss to a non-active cooperatives. Credit unions in the Kepanjen District there are 13 cooperatives are scattered in several places in the District of Kepanjen, including 11 cooperatives belonging to the category is still active and 2 cooperatives that have been inactive. This is evidence of the lack of internal control systems. Therefore opening of competent financial manager, internal control system, and utilization of technology to produce high quality financial report. Based on the above, and to obtain empirical evidence of how the analysis of the effect of the competence of financial manager, internal control system, and utilization of information technology on the quality of financial reports ..

\section{Literature Review}

2.1 Competence Financial Manager

Definition of competence in explanation of Article 3 PP 102018 that, which referred to the competence is the ability and characteristics possessed by civil servants in the form of knowledge, skills, and attitudes necessary behavior in the execution of his office. The ability of the human resources that are essential for success and purpose in an organization. According Thoha (2008), competence is a description of what a person must do in order to carry out his work properly. 
Law No. 13 of 2003 on Employment Article 1, paragraph 10 states that competence is the ability of each individual that covers aspects of knowledge, skills and attitudes that work in accordance with established standards. Education Minister Decree No. 045 / U / 2002 on Higher Education Core Curriculum proposed "Competence is a set of intelligent action, the full responsibility of a person as a condition to be considered capable by the public in carrying out tasks in certain occupations". Determining the level of competence needed in order to determine the level of performance expected for the category of good or average. According to Prayitno (BKN, 2003: 11) and Thoha (2008: 28) states that there are three standards of competence, namely: knowledge skills attitude.

\subsection{Internal Control System}

Based on the Indonesian Government Regulation No. 60 of 2008 on the Internal Control System of the Government, the internal control system is a process that is integral to the actions and activities that are carried out continuously by the management and all employees to provide reasonable assurance for the achievement of organizational goals through effective and efficient, reliability of financial reporting, the safeguarding of state assets, and compliance with laws and regulations.

The purpose of the internal control system according to Mulyadi (2016) is keeping the property of the organization, check the statutes and the correctness or reliability of accounting data, improve or promote the efficiency or the operations, encourage compliance with management policies that have been set. According Kumaat (2011), at the organization level control objectives related internal control with the reliability of financial reporting, timely feedback on the achievement of operational objectives and strategies, as well as legal and regulatory compliance.

The basic gist of the Indonesian Government Regulation No. 60 of 2008, was the creation of a Government Internal Control System (SPIP) which can realize a good governance practices. The internal control structure consists of five main elements according to Bastian (2007: 11). These five basic elements are: control environment, risk assessment, control activities, information and communication, monitoring. The principles of the internal control system according to Joseph (2005) including specification of responsibilities clearly, the implementation of adequate record- keeping, wealth enrichment and company employees, the separation of recording and storage assets, separation of responsibility for a transaction related to, the use of technical equipment, the implementation of inspection independent.

\subsection{Utilization of Information Technology}

Information technology in addition to functioning as a computer technology for the processing and storage of information, it also has a function as a communication technology for the delivery and dissemination of information. According Trisaputa (2013) "Information technology plays a role in providing useful information for decision-makers within the organization, including in terms of reporting to support decision-making processes more effectively".

The local government is obliged to develop and exploit advances in information technology to improve the financial management area, and distribute financial information to the public services area. With the rapid advancement of information technology and the potential for widespread utilization, it can open up opportunities for various parties to access, manage, and utilize regional financial information quickly and accurately. Liabilities use of information technology by government and local government stipulated in Government Regulation No. 56 Year 2005 concerning Regional Financial Information System. With the information technology is expected to help in the financial reporting process so that it can generate financial reports that are reliable and timely.

\subsection{The Quality of Financial Report}

The financial report of an entity is an information note on the accounting period that can be used to describe the performance of the entity. Statement of the Government Accounting Standards (SAP) No. 1 illustrates the definition of the financial statements as a structured report on the financial position and transactions undertaken by a reporting entity. The financial report into a tool that is used to show the gains and the implementation of the accountability functions within an entity. According Mardiasmo (2009), accounting and financial reports imply as a process of collecting, processing, and communicating useful for decision-making as well as to assess the performance of the organization.

According to Government Regulation 71 Year 2010 concerning the Government Accounting Standards accrual stating "qualitative characteristics of financial report is a normative measures that need to be realized in the accounting information so that it can fulfill its purpose". The following four characteristics is a prerequisite normative required in preparing the financial statements, namely: relevant, reliable, understandable, can be compared.

\subsection{Conceptual Framework}

Here is the conceptual framework of the study. 


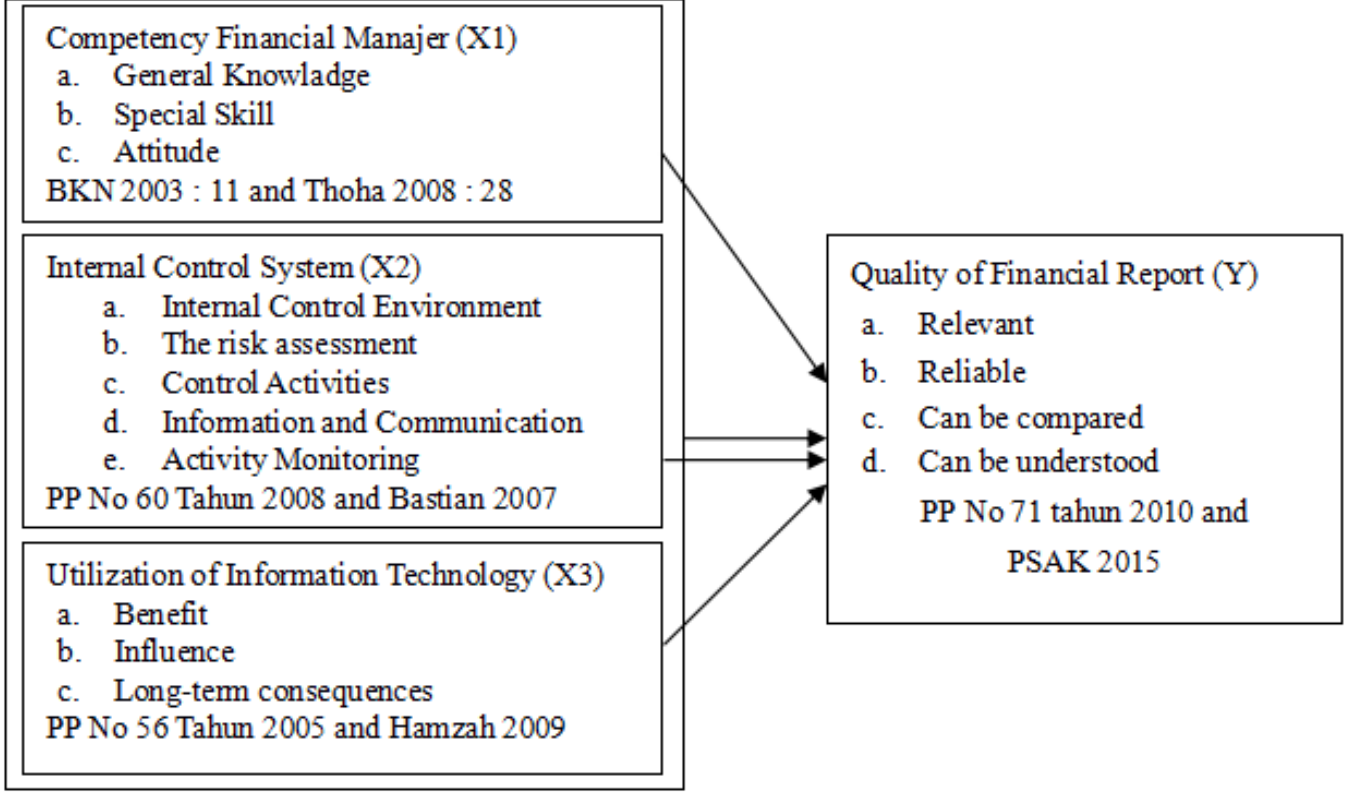

Figure 1. Conceptual Framework

Based on the above framework,: On variables X1 competency of financial manager has 3 indicators namely general knowledge, special skill, attitude. On variables X2 internal control system has 5 indicators namely internal control environment, the risk assessment, control activities, information and communications, activity monitoring. On variables X3 utilization of information technology has 3 indicators namely benefit, influence, long-term consequences. On variables $\mathrm{Y}$ quality of financial report has 4 indicators namely relevant, reliable, can be compared, can be understood.

\section{Hypothesis}

H1: Competence of financial manager, internal control system, and utilization of technology information affects the quality of financial report

$\mathrm{H} 2$ : Competence financial managers affects the quality of financial report

H3: Internal control system affects the quality of financial report

H4: The information technology affects the quality of financial report

\section{Methods}

This study uses a quantitative approach, the research uses data that can be calculated to produce a strong quantitative interpretation (Passalong, 2012). The independent variable in this research is the competence of financial management, internal control system, and the use of information technology. While the dependent variable is the quality of financial reporting.

This research was conducted on the 11th of Credit Unions in the Kepanjen District. The population in this study is part of a financial manager at the Credit unions. With non-probability sampling technique sampling is chosen saturation sampling (census). Thus, the samples were 45 employees on the part of financial management in the District 11 Credit Unions Kepanjen.

The data collection is done by distributing questionnaires and using likert scale. Data analysis using statistical parametric form of correlation and regression with $\mathrm{t}$ test to determine the significance between the variables studied.

\section{Results}

Correlation coefficient values between the competence of financial manager with the quality of the financial report amounted to 0.623 , the internal control system with the quality of financial report amounted to 0.759 , use of information technology to the quality of the financial statements amounted to 0.761 . The coefficient of determination $\mathrm{r} 2$ of 0,646 . It gives the user the relationship between the competence of financial manager, internal control system, and utilization of information technology on the quality of the financial report was substantial at 0.804 .

The results of analysis following regression equation: $\mathrm{Y}=3.475+0.017 \mathrm{X} 1+0.410 \mathrm{X} 2+0.422 \mathrm{X} 3$. From the regression equation can be informed that: (1) the constant of 3.475 means that if the competence of financial manager, internal control system, and utilization of information technology are researched constant and equal to zero then the quality of financial reporting by 3.475. (2) the regression coefficient of competence financial manager of 0.017 means that if the competence of financial manager increased by 1 scale in the respondents' answers, the 
quality of financial report will be increased by 0,017 . Assuming no additional (constant) values of competencies financial manager. (3) the regression coefficient of the internal control system at 0,410 means that if the internal control system increased by 1 scale in the respondents' answers, the quality of financial report will be increased by 0.410 . Assuming no additional (constant) value of the internal control system. (4) the regression coefficient of 0.422 utilization of information technology means that if the use of information technology increased by 1 scale in the respondents' answers, the quality of financial report will be increased by 0.422 . Assuming no additional (constant) value of information technology. 422 means that if the use of information technology increased by 1 scale in the respondents' answers, the quality of financial report will be increased by 0.422 . Assuming no additional (constant) value of information technology. 422 means that if the use of information technology increased by 1 scale in the respondents' answers, the quality of financial report will be increased by 0.422 . Assuming no additional (constant) value of information technology.

F test results obtained significance value of 0.000 which is much smaller than 0.05 , so it is clear that the competence of financial manager, internal control system, and utilization of information technology together affect the quality of financial reporting. Thus H1 stating that the competence of financial manager, internal control system, and utilization of information technology together affect the quality of financial reporting statistically acceptable.

$\mathrm{T}$ Test Results on variable competencies financial manager obtained significance value of 0.908 which is far greater than 0.05 , so it is clear that the competence of the financial manager does not affect the quality of financial reporting. Thus $\mathrm{H} 2$ stating that the competence of the financial manager does not affect the quality of the financial report can not be accepted statistically. On the internal control system variables obtained significance value of 0.015 which is much smaller than 0.05 , so it is clear that the internal control system affects the quality of financial reporting. Thus $\mathrm{H} 3$ stating that the internal control system to influence the quality of financial reporting statistically acceptable. In the variable utilization of information technology obtained significance value of 0.013 which is much smaller than 0.05 , so it is clear that the utilization of information technology affect the quality of financial reporting. Thus $\mathrm{H} 4$ which states that the utilization of information technology affect the quality of financial reporting statistically acceptable.

\section{Discussion \\ 6.1 Effect of Competence Financial Manager, Internal Control Systems and Utilization of Information Technology Quality on The Quality of Financial Report}

In the first hypothesis is the competence of financial manager, internal control system and utilization of information technology affect the quality of financial reporting. Competence of financial managers in the variable should correspond to the accounting or finance to fill the position or positions of a financial institution so as to improve the quality of financial reporting on credit unions. In the variable internal control system also requires the reliability of financial report that is useful to provide financial information. And the variable utilization of information technology has been fully delivering the expected results, especially in improving the quality of financial reporting. The results of multiple linear regression analysis showed that the test together of variable competence of financial manager, internal control system, and utilization of information technology with sig 2 tailed 0.000 (sig $>0.05$ ), which means there is a positive and significant influence. From the results of this research hypothesis then in line with the research by Mutiana (2017). Mutiana research results show that together the independent variable (the system of internal control, information technology, human resources) have a significant effect on the dependent variable (the quality of the financial report).

\subsection{Effect on the Quality Competence Financial Manager on The Quality Of Financial Report.}

In the second hypothesis of this study is that the competence of financial manager affect the quality of financial reporting. This means that employees in the field of financial management credit unions which have competence in accounting or finance who fills the position or positions of a financial institution will improve the quality of financial reporting on credit unions. However, this hypothesis is much different from the analysis of research that shows that the competence of the financial manager negative effect (no effect) on the quality of financial reporting. These results show that the leadership of credit unions are still lacking in the placement of part of financial manager that have competence in the field of accounting. Credit unions could still be looking for replacement solutions in the areas of financial manager should be adjusted in the field. Lack of financial managers placement section looks at the results of studies showing that the respondent's educational background from other departments such as the one with the strata graduates majoring in education, religion, technology and education IPS. And there is also the graduates of vocational or SMEA is already in a position of financial manager. According to the results of research educational background other than accounting and management shows the magnitude of as much as $26.7 \%$ of respondents. As well as the last graduates of vocational education as much as $13.3 \%$ and 2.2\% SMEA.

Determining the level of competence of financial manager is measured by three indicators of knowledge, skills, attitude. Based on data from respondents, the average education level of the background is S1 Accounting education $42.2 \%$. Respondents on average choose answers in expanding knowledge of the financial sector need to 
be needed literature in the form of journals and books on finance which is at a very high 4.36 area. This means that financial managers still need to develop science in finance with many reference books read about finances. $\mathrm{T}$ test results showed the Sig 2 tailed amounted to 0.908 (the value of Sig.> 0.05).

Financial manager on credit unions, which should have competence in the field of specializations of each so it can complete its tasks and functions, is now the competence of financial managers do not affect the quality of financial reporting. In fact, shows the results of interviews conducted by the researchers that there are many savings and loans less training so that employees of the financial manager is difficult to understand the material in the absence of the basic science of accounting education and the lack of guidance from the leadership. In the item description variable question the competence of financial manager also shows the results of respondents are still many people will answer information does not agree. Answer disagree is on the question of the 2nd of 3 respondents $(6,7 \%)$, which describes the technique understand of work performed in accordance with the standards of professional ethics. From the results of these answers indicate that there were respondents who do not understand on the part of financial manager in accordance field. Then the question 9th at 3 respondents $(6.7 \%)$, which describes the ability and skill in analyzing transactions and financial reporting process. From these answers show that the proficiency and skills in analyzing transactions and financial reporting process is still lacking. On the question does not agree next is the question to 11 by 1 respondent (2.2), which explains that the application of ethics and codes of conduct cooperative as financial manager. From these answers indicate that the lack of application of ethics and codes of conduct credit unions.

\subsection{Effect of the Internal Control System on the Quality of Financial Report}

In the third hypothesis in this study is the internal control system affects the quality of financial reporting. The control systems also require the reliability of financial report that is useful to provide financial and performance information for internal and external parties. Internal control systems are all activities of company management that includes planning, organizing, and directing the implementation of measures to manage risk and to improve the achievement of the goals and objectives set. To achieve a good governance practices within a financial institution then has to be a system that is the internal control system. So based on the results of this study indicate that the internal control system has a positive effect on the quality of the financial report.

The key elements in the internal control system is measured through five indicators, namely the control environment, risk assessment, information and communication, control activities, and monitoring. Based on data from respondents, the average in the region of "Very High" is equal to 4.36. From these scores show that in the cooperative financial institutions have mechanisms to anticipate and address emerging risks as well as the identity of the asset is put on meubelair, equipment and office inventory. The result of the influence of the internal control system of the quality of financial reports was also supported by the answers of respondents to the item description that the average question answered strongly agree and agree on every item question. $T$ test results showed values of 0.015 tailed Sig 2 (value Sig. <0.05).

\subsection{Effect of Utilization of Information Technology on the Quality of Financial Report}

In the fourth hypothesis that the utilization of information technology affect the quality of financial reporting. Information technology plays an important role in an organization, especially in the financial institution. This refers to the usefulness of a computer technology in the processing, storage, delivery, and dissemination of data a company. Useful for financial managers to take a decision in terms of reporting to facilitate the decision-making process and more effective. So that the results showed that the use of information technology has a positive effect on the quality of the financial report.

Use of information technology is measured in three indicators of the benefits, and the effects of long-term consequences. Based on respondents' answers to the data, average -rata in the region of "Very High" is equal to 4.40. From these scores show that internet networks available to facilitate the work. On average respondents agree on every item question. T test results showed the Sig 2 tailed amounted to 0,013 (the Sig. <0.05). Based on the results of hypothesis testing, we can conclude that the use of information technology affect the quality of financial reporting. The realization of the quality of financial reports on credit unions also depend on the progress of the technology used. Using on utilization of information technology is to achieve the primary quality of the financial reporting of the cooperative.

\section{Conclusion}

Based on the description that has been said before we can conclude several things: First, the competence of financial manager variable (X1), the internal control system (X2), and utilization of technology (X3) positive effect on the quality of financial reporting. This is indicated by the F test results in table Annova, calculated $\mathrm{F}$ value of 24.913 and 0.000 significance value. With a significance level of $<5 \%(\alpha=0.05)$. It can be concluded that the competence of financial manager, internal control system and the utilization of technology information affects the quality of the financial report. Second, the competence of financial manager effect on the quality of financial 
reporting. This is indicated by the results of the T test, variable competence of financial managers at 0.908 greater than 0.05 . This means that the lack of competence of financial manager, the more the lack of qualified financial results. Third, the internal control system significant effect on the quality of financial reporting. This is indicated by the results of the $T$ test, the internal control system variable of 0.015 is less than 0.05 . This means that the better implementation of the internal control system the better the quality of the resulting financial report. Fourth, utilization of information technology a significant effect on the quality of financial report. This is indicated by the results of the $T$ test, variable utilization of information technology for 0.013 less than 0.05 . This means that the better use of information technology the better the quality of the resulting financial report. internal control systems significant effect on the quality of financial reporting.

\section{Suggestions}

Some suggestions are given on the results of this study were (1) For subsequent researchers expected to add the variables and add the sample to prove the return variables in this study. (2) This study is expected to add a wider research object to strengthen the research results. (3) Credit Unions in the District of suggested Kepanjen can improve their competence in financial managers in order to produce high quality financial statements.

\section{References}

AICPA (American Institut of Certified Public Accountants), Statement of The Accounting Principles Board. (2012). Yogyakarta: BPFE

Chodijah, Siti. (2018). Pengaruh Pemenfaatan Teknologi Informasi, dan Sistem Pengendalian Internal Terhadap Kualitas Laporan Keuangan Pemerintah Daerah. Studi Kasus SKPD Provinsi DKI Jakarta.. Journal of Accounting, 8 (1), March 1st

COSO. (2013). Internal Control - Integrated Framework : Executive Summary Durham. North Carolina May 2013 Darmawan, Deni. (2015). Pendidikan Teknologi Informasi dan Komunikasi. Bandung: PT. Youth Rosdakarya Efraim Turban. (2005). Decission support System and Intelligent System. Yogjakarta: ANDI Government Regulation No. 101 of 2000 on Competence

Government Regulation No. 56 Year 2005 Concerning Regional Financial Information System

Government Regulation No. 71 Year 2010 on Accrual-Based Government Accounting Standards

Government Regulation No.60 of 2008 on the Internal Control System of Government

Halim, Abdul. (2012). Akuntansi Sektor Publik, Akuntansi Keuangan Daerah (4 ${ }^{\text {th }}$ ed.). Jakarta: Four Salemba.

Hanifa, Lia. (2016). Pengaruh Kompetensi Pengelola Keuangan dan Sistem Akuntansi Keuangan Daerah Terhadap Kualitas Laporan Keuangan. Progress Journal of Economic Development. 2 (1)

Harvesi, GA (2005). Standards for Internal Control in the New York State Government. www.osc.state.ny.us Husein, Umar. (2013), Metode Penelitian Untuk Skripsi dan Tesis Bisnis. (2 ${ }^{\text {nd }}$ ed.). Jakarta: Rajawali Press Ikhwanul, Irfan. (2008), Pengaruh Pemanfaatan Teknologi Informasi dan Pengawasan Keuangan Daerah Terhadap Kualitas Laporan Keuangan Daerah. Journals. Article.

Indra. Bastian. (2006). Akuntansi Sektor Publik: Suatu Pengantar. Jakarta: Erlangga

COSO. (2013). Internal Control-Integrated Framework

Law No. 13 of 2003 on Manpower

Law paragraph 1 of 1945 on Cooperatives

Mahmudi. (2007). Manajemen Kinerja Sektor Publik. Yogyakarta: Publishing and Printing Unit College of Management Sciences YKPN.

Mardiasmo. (2009). Akuntansi Sektor Publik. Yogyakarta: Andi

Mokoginta. (2017). Pengaruh Sistem Pengendalian Intern dan Sistem Akuntansi Keuangan Daerah terhadap Kualitas Laporan Keuangan Pemerintah. Journal of Accounting Research Going Concern 12 (2)

Mulyadi. (2012). Sistem Akuntansi. (3 ${ }^{\text {rd }}$ ed.), Fourth Printing. Jakarta: Salemba.

Mutiana, Liza. (2017). Pengaruh Sistem Pengendalian Intern, Teknologi Informasi, Kualitas Sumberdaya Manusia dan Komitmen Organisasi terhadap Kualitas Laporan Keuangan. Journal of Economic Perspectives Darussalam

Sugiyono. (2016). Metodologi Penelitian Kuantitatif, Kualitatif dan R\&D. Bandung: Alfabeta

Susanto, Azhar. (2008). Sistem Informasi Akuntansi. Jakarta: Gramedia

Sutarman. (2012). Pengantar Teknologi Informasi. Jakarta: Earth Literacy

Wahyono, T. (2004). Sistem Informasi (Konsep Dasar, Analisis, Desain dan Implementasi. Yogyakarta: Graha Science.

Wati, Desiana. (2014). Pengaruh Kompetensi SDM Penerapan SAP, dan Sistem Akuntansi Keuangan Terhadap Kualitas Laporan Keuangan Daerah. Journal of Accounting Program. 2 (1)

Wilkinson, Et.al. (2000). Accounting Information System Essential Concept and Aplication. New York USA 